\title{
Analisis Deformasi Gunung Merapi Berdasarkan Data Pengamatan GPS Februari- Juli 2015
}

\author{
Yuandhika Galih Wismaya, Ira Mutiara Anjasmara, dan Sulistiyani \\ Jurusan Teknik Geomatika, Fakultas Teknik Sipil dan Perencanaan, Institut Teknologi Sepuluh Nopember (ITS) \\ Jl. Arief Rahman Hakim, Surabaya 60111 Indonesia \\ e-mail: ira@geodesy.its.ac.id, sulistiyani@esdm.go.id
}

\begin{abstract}
Abstrak-Gunung Merapi adalah gunung api yang terletak di provinsi Daerah Istimewa Yogyakarta dan Jawa Tengah. Gunung Merapi merupakan salah satu gunung api paling aktif di Indonesia dimana Gunung Merapi memiliki periode letusan yang relatif cepat yaitu sekitar 2-7 tahun sekali. Dengan cepatnya aktivitas vulkanik yang terjadi pada Gunung Merapi, maka diperlukan suatu upaya mitigasi dalam meminimalisir bahaya letusan Gunung Merapi, dan salah satu upaya tersebut adalah pengamatan deformasi menggunakan teknologi GPS. Karakteristik deformasi yang dikaji meliputi posisi, arah, dan besar pergeseran. Dari analisis unsur deformasi tersebut, dapat diketahui karakteristik deformasi pada Gunung Merapi. Untuk pengloahan data GPS digunakanlah scientific software yaitu GAMIT/GLOBK. Dari hasil analisis yang dilakukan selama 6 bulan, yaitu bulan Februari hingga Juli 2015, didapatkan nilai pergeseran horizontal sebesar 0,01822 meter menuju ke arah barat laut dan vertikal sebesar $\mathbf{- 0 , 0 6 9 2 4}$ meter dengan sifat deflasi untuk stasiun DELS, horizontal sebesar 0,030508 meter menuju ke arah barat daya dan vertikal sebesar $\mathbf{- 0 , 0 0 8 7 5}$ meter dengan sifat deflasi untuk stasiun GRWH, horizontal sebesar 0,025822 meter menuju ke arah tenggara dan vertikal sebesar 0,07725 meter dengan sifat inflasi untuk stasiun KLAT.
\end{abstract}

Kata Kunci-Deflasi, Deformasi, Gunung Merapi, GPS, Inflasi

\section{PENDAHULUAN}

$I^{\mathrm{r}}$ NDONESIA adalah negara kepulauan yang secara tektonik terletak diantara pertemuan tiga lempeng benua yaitu lempeng Eurasia, lempeng Pasifik, serta lempeng Australia. Interaksi dari ketiga lempeng tersebut menghasilkan deretan pegunungan api (volcanic arc) yang membujur dari selatan hingga timur Indonesia. Terhitung sebanyak 129 buah gunung api aktif berada di Indonesia [1]. Manifestasi dari keberadaan gunung api tersebut tentunya memiliki dampak secara langsung terhadap lingkungan baik itu positif atau negatif, salah satu dampak negatifnya adalah bahaya letusan gunung api. Letusan gunung api merupakan proses naiknya material magma dari dalam bumi menuju permukaan bumi baik dikeluarkan secara eksplosif maupun efusif [2].

Gunung Merapi merupakan salah satu gunung api yang menunjukkan gejala vulkanisme paling aktif di dunia [2], hal tersebut dibuktikan dengan periode letusan yang pendek dari Gunung Merapi yaitu sekitar 2-7 tahun. Dengan pendeknya periode letusan dari Gunung Merapi menunjukkan tingginya aktivitas yang terjadi pada dapur magma, hal ini berimplikasi terhadap perubahan bentuk badan atau permukaan berupa mengembang (inflation) dan mengempisnya (deflation) permukaan gunung tersebut. Perubahan yang signifikan dari permukaan gunung api dapat menjadi salah satu indikator akan terjadinya letusan, untuk itu diperlukan pengamatan deformasi yang dilakukan secara berkala dengan melihat perubahan nilai pergeseran permukaan baik dari arah vertikal maupun horizontal. Pengamatan deformasi menggunakan GPS merupakan salah satu metode yang sangat efektif karena dapat mengamati perubahan bentuk permukaan secara kontinyu, GPS juga tidak memerlukan keterlihatan antar titik pengamatan sehingga posisi titik GPS dapat tersebar dan menggambarkan bentuk gunung api secara keseluruhan, dan yang terakhir GPS dapat menghasilkan data dengan ketelitian hingga orde $\mathrm{mm}$ (milimeter) dengan menggunakan metode Differential Positioning [3].

Pada penelitian ini metode yang digunakan untuk mengamati besarnya deformasi dari Gunung Merapi adalah metode GPS. Didapatkan data GPS dan dilakukan pengolahan data yang bersifat kontinyu dalam kurun waktu Februari hingga Juli tahun 2015. Data tersebut diolah menggunakan software GAMIT/GLOBK untuk mengetahui posisi, arah, dan besar pergeseran suatu titik pengamatan dari waktu ke waktu.

\section{METODOLOGI PENELITIAN}

\section{A. Lokasi Penelitian}

Lokasi penelitian utama terletak pada kawasan Gunung Merapi, dimana secara geografis lokasinya terletak pada koordinat $07^{\circ} 32^{\prime} 30^{\prime \prime}$ - $07^{\circ} 52^{\prime} 30^{\prime \prime}$ LS dan $110^{\circ} 15^{\prime} 00^{\prime \prime}$ $110^{\circ} 37^{\prime} 30^{\prime \prime}$ BT. Secara administratif Gunung Merapi terletak pada perbatasan empat kabupaten yaitu Kabupaten Sleman, Provinsi Daerah Istimewa Yogyakarta dan Kabupaten Magelang, Kabupaten Boyolali, serta Kabupaten Klaten yang terletak di provinsi Jawa Tengah. Gunung Merapi memiliki ketinggian $2978 \mathrm{dpl}$, diameter sebesar $28 \mathrm{~km}$, luas 300-400 km² dan volume $\pm 150 \mathrm{~km}^{3}[1]$.

\section{B. Data dan Peralatan}

1. Data

Data yang digunakan adalah data RINEX GPS hasil pemantauan online dari kantor BPPTKG. Titik GPS yang digunakan sebanyak empat titik pengamatan, dimana satu titik sebagai titik ikat yaitu stasiun GPS BPTK yang berada di kantor BPPTKG dan tiga lainnya sebagai titik pengamatan yaitu 
stasiun GPS DELS, GPS GRWH, dan GPS KLAT yang berada di sekitar Gunung Merapi. Didapatkan data GPS dalam format rinex sebanyak 24 data untuk waktu satu hari, dikarenakan stasiun GPS tersebut melakukan akuisisi data setiap jam dengan sampling pengukuran tiap 1 detik. Rentang waktu dari data yang digunakan dalam penelitian adalah 6 bulan, yaitu bulan Februari sampai Juli 2015.

Tabel 1.

Lokasi Stasiun Pengamatan GPS

\begin{tabular}{ccc}
\hline \hline No & Stasiun & Lokasi \\
\hline 1 & BPTK & BPPTKG, Yogyakarta \\
2 & DELS & Deles, Klaten \\
3 & GRWH & Grawah, Boyolali \\
4 & KLAT & Klatakan, Magelang \\
\hline \hline
\end{tabular}

Selain data RINEX GPS terdapat juga file penunjang yang harus dimiliki yaitu file gelombang pasang surut (otl_FES2004.grd), file atmosfer (atmdisp_YYYY), file pemodelan cuaca (vmflgrd.YYYY), serta h-file global sebanyak DOY (Day Of Year) yang akan diolah. Kegunaan dari file penunjang ini adalah untuk pengolahan data GPS menggunakan software GAMIT/GLOBK.

\section{Peralatan}

Peralatan yang digunakan pada penelitian ini dapat dibagi menjadi 2, yaitu perangkat keras berupa laptop sebagai pusat pengolahan data dan perangkat lunak sebagai penunjang seperti software TEQC untuk penggabungan data Rinex, software scientific GAMIT/GLOBK untuk pengolahan data GPS, software GMT untuk melakukan plotting dari hasil penelitian, dan Microsoft Office untuk penulisan laporan.

\section{Diagram Alir Pengolahan Data}

Berikut adalah penjelasan diagram alir pengolahan data:

1. Mempersiapkan data

Pengumpulan data merupakan tahap awal untuk mempersiapkan data yang akan diolah, dalam hal ini data GPS didapatkan melalui stasiun pengamatan GPS milik kantor BPPTKG. Data RINEX GPS yang diperoleh berupa data pengamatan per-jam, untuk mendapatkan data RINEX dalam 1 hari maka dilakukan penggabungan dengan software TEQC.

\section{Pengolahan menggunakan GAMIT \& GLOBK}

Pertama lakukan pembuatan direktori kerja untuk menyimpan data RINEX GPS serta file control. Kemudian lakukan editing darifile control. Setelah tahapan editing selesai, lakukan proses pengolahan data dengan GAMIT secara automatic batch processing yaitu dengan melakukan perintah "sh_gamit -s yyyy $d d d_{1} d d d_{2}$-expt [expt]". Hasil keluaran dari pengolahan GAMIT adalah h-files.

Berikutnya adalah menjalankan proses pengolahan dari software GLOBK untuk menghasilkan kecepatan pergeseran secara time series dan koordinat estimasi. Sebelum menuju ke dalam GLOBK lakukan konversi h-file hasil dari GAMIT menjadi file biner. Setelah melakukan konversi lakukan perintah "sh_glred -s $Y Y Y Y_{1} D D D_{1} Y Y Y Y_{2} D D D_{2}$-expt [expt]opt H G E" [4].

3. Analisa pergeseran tiap titik.

Dari hasil pengolahan software GAMIT/GLOBK, dilakukan uji t-student untuk menguji nilai kecepatan pergeseran hasil dari software GAMIT/GLOBK secara kualitatif.
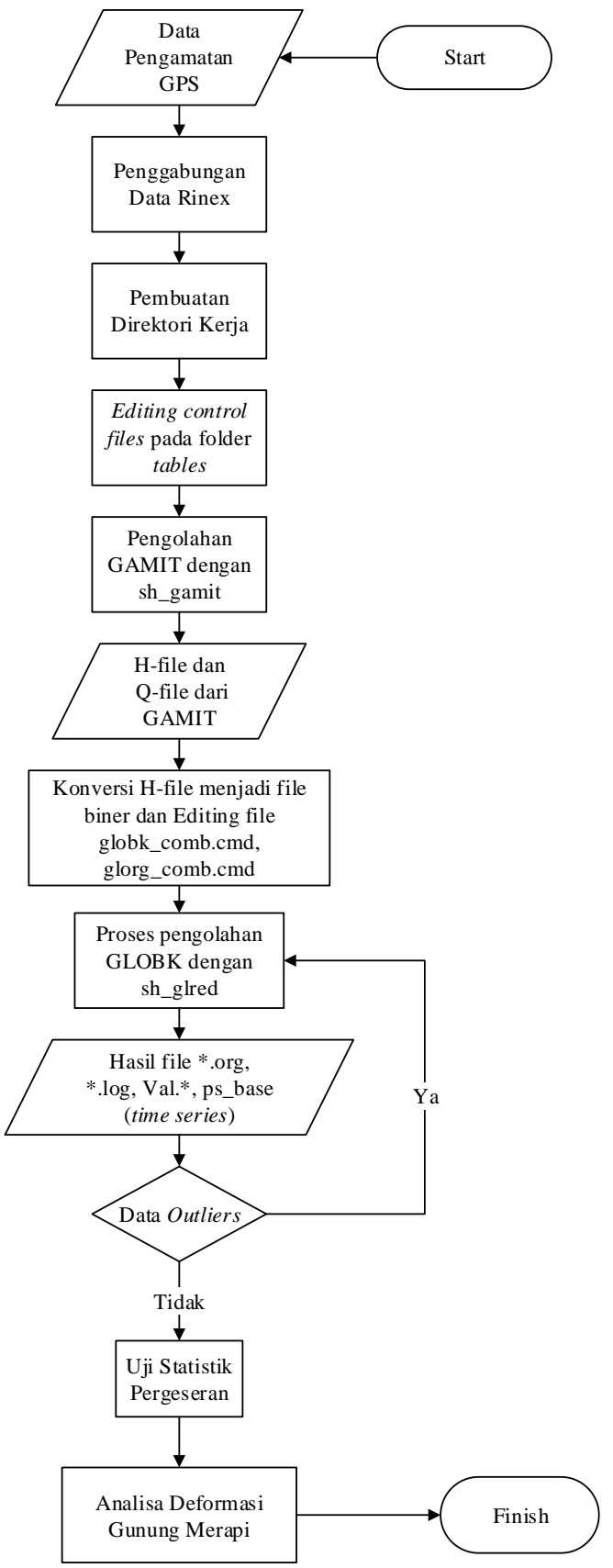

Gambar 1. Diagram Tahap Pengolahan Data

\section{HASIL DAN ANALISA}

\section{A. Hasil Pengolahan Data GPS}

Pengolahan data GPS dilakukan menggunakan software GAMIT/GLOBK, pengolahan dilakukan untuk mendapatkan koordinat estimasi beserta besar vektor pergeseran dari stasiun GPS Gunung Merapi yang terjadi pada kurun waktu Februari hingga Juli 2015. Pengolahan dilakukan menggunakan software GAMIT, didapatkanlah solusi berupa h-file sebanyak DOY yang diteliti. Setelah didapatkan solusi dari proses pengolahan GAMIT, tahapan pengolahan dilanjutkan menggunakan software GLOBK. Dalam pengolahan GLOBK 
didapatkan koordinat geosentrik ataupun toposentrik yang selanjutnya akan diamati pergerakan posisinya secara time series sehingga dapat diketahui besar pergeseran titik GPS. Berikut ini adalah contoh tampilan dari plotting time series dari titik DELS dalam arah utara.

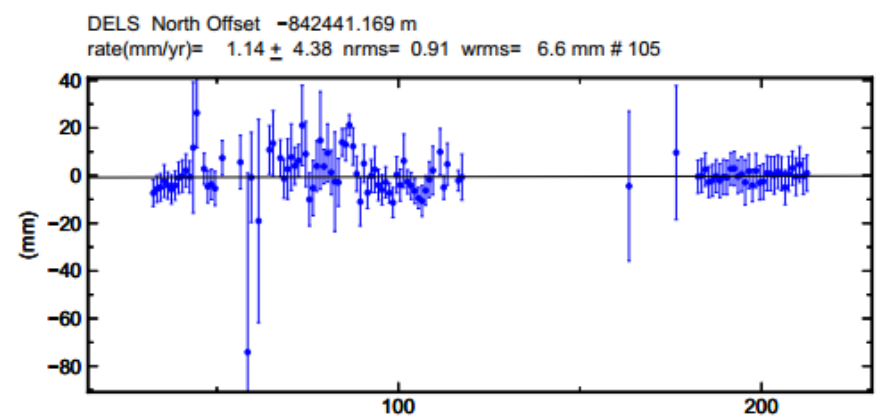

Gambar 2. Plotting Time Series North Stasiun DELS

\section{B. Vektor Pergeseran}

Vektor pergeseran adalah besaran yang menyatakan perubahan yang terjadi terhadap titik pengamatan dalam selang waktu tertentu. Acuan dalam mendapatkan kecepatan pergeseran adalah sesi pertama pengamatan masing-masing stasiun terhadap suatu sesi tertentu. Nilai pergeseran yang dihasilkan dari suatu sesi pengamatan dapat bernilai minus (-) atau plus (+) yang dapat mempengaruhi arah pergeseran.

Tabel 2.

Vektor Pergeseran Titik Ikat BPTK

\begin{tabular}{ccccc}
\hline \hline \multirow{2}{*}{ No } & \multirow{2}{*}{ Stasiun } & \multicolumn{3}{c}{ Februari-Juli 2015 } \\
\cline { 3 - 5 } & & $\mathrm{dE}(\mathrm{m})$ & $\mathrm{dN}(\mathrm{m})$ & $\mathrm{dU}(\mathrm{m})$ \\
\hline 1 & DELS & $-0,01627$ & 0,0082 & $-0,06924$ \\
2 & GRWH & $-0,01937$ & $-0,02357$ & $-0,00875$ \\
3 & KLAT & 0,02418 & $-0,00906$ & 0,07725 \\
\hline \hline
\end{tabular}

\section{Analisa Vektor Pergeseran}

Setelah mengetahui besar pergeseran titik GPS dari Gunung Merapi selama enam bulan maka perlu dilakukan pengujian statistik untuk melihat hasil dari pergeseran, tidak hanya secara kuantitatif namun juga secara kualitatif, apakah titik stasiun GPS tersebut mengalami pergeseran atau tidak. Uji statistik yang dilakukan adalah uji-t student. Uji statistik dilakukan dengan menguji variabel pergeseran titik $\left(\mathrm{P}_{\mathrm{xy}}\right)$ dari sesi pengamatan $\mathrm{x}$ ke sesi pengamatan y yang nilainya dapat dihitung menggunakan rumus:

$$
P_{x y}=\sqrt{\left(d n_{x y}{ }^{2}+d e_{x y}{ }^{2}\right.}
$$

Sedangkan untuk standar deviasi dari setiap titik pengamatan dapat dihitung menggunakan rumus:

$$
\text { Std } P_{x y}=\sqrt{(s d} d n_{x y}{ }^{2}+s d d e_{x y}{ }^{2}
$$

Hipotesis nol yang dilakukan pada uji statistik ini adalah titik pengamatan tidak bergeser dalam selang waktu $\mathrm{x}$ dan $\mathrm{y}$ sehingga:

Hipotesis nol $\quad \mathrm{H}_{0}: \mathrm{P}_{\mathrm{xy}}=0$

Hipotesis alternatif $\mathrm{H}_{1}: \mathrm{P}_{\mathrm{xy}} \neq 0$
Kemudian dilakukan pengujian pergeseran titik pengamatan seperti berikut:

$$
T=P_{x y} / S t d P_{x y}
$$

Pergeseran dinyatakan signifikan atau hipotesis nol ditolak jika [5]:

$$
T>t_{d f}, \propto / 2
$$

$d f$ diasumsikan tak terhingga karena data yang diamati sangat banyak dengan rate akuisisi data tiap 1 detik, oleh karena itu digunakan tabel $t$-distribution dengan selang kepercayaan 95 $\%$ sehingga nilai dari uji hipotesis signifikan seperti Rumus 4 adalah sebesar 1,960. Tabel 3 berikut menunjukkan besar

\begin{tabular}{|c|c|c|c|c|}
\hline Stasiun & $\mathrm{dN}(\mathrm{m})$ & $\mathrm{dE}(\mathrm{m})$ & Std N & $\operatorname{Std} E$ \\
\hline DELS & 0,0082 & $-0,0162$ & 0,002 & 0,006 \\
\hline GRWH & $-0,0235$ & $-0,0193$ & 0,001 & 0,008 \\
\hline KLAT & $-0,0090$ & 0,0241 & 0,002 & 0,005 \\
\hline Stasiun & $\mathrm{P}$ & Std P & $\mathrm{T}$ & Pergeseran \\
\hline DELS & 0,0182 & 0,006 & 2,7609 & Ya \\
\hline GRWH & 0,0305 & 0,008 & 3,4321 & Ya \\
\hline KLAT & 0,0258 & 0,006 & 4,2870 & $\mathrm{Ya}$ \\
\hline
\end{tabular}
pergeseran yang terjadi di semua stasiun.

Tabel 3.

Hasil Uji Statistik Vektor Pergeseran Horizontal

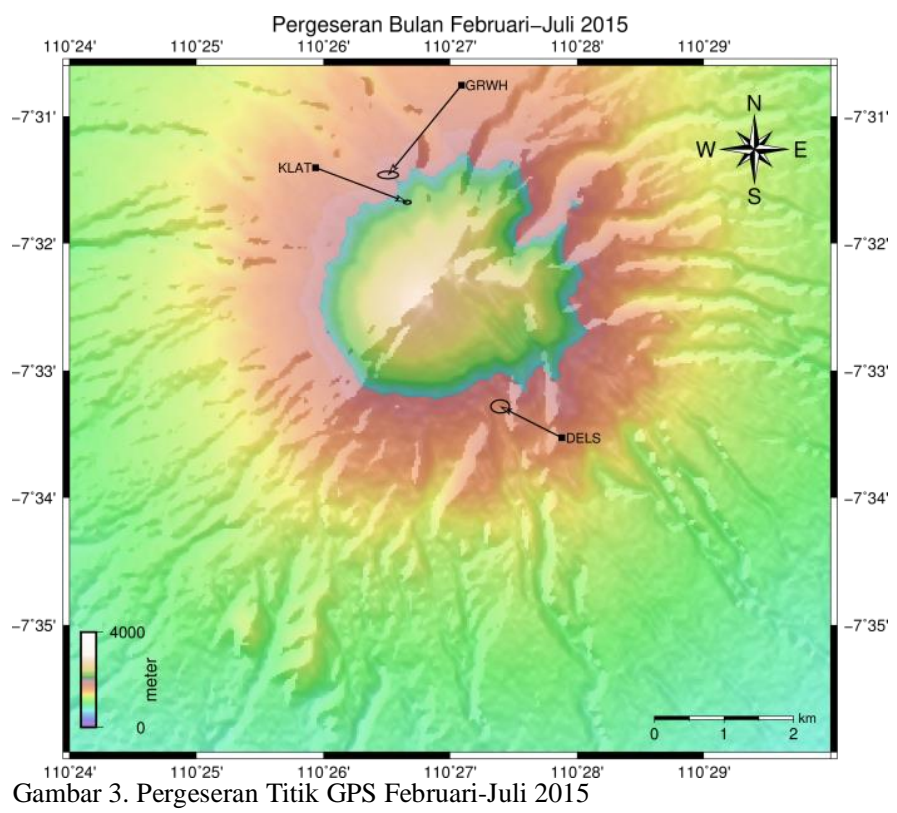

\section{Analisa Deformasi}

Pemantauan aktivitas gunung api melalui metode deformasi dapat diketahui melalui proses monitoring inflasi dan deflasi akibat perubahan tekanan dari dalam tubuh gunung api. Proses perubahan badan gunung api tersebut dapat terekam melalui perubahan jarak antar titik pengamat dengan titik ikat (baseline). Berikut merupakan hasil perubahan jarak antara titik pengamatan dengan titik ikat BPTK dalam rentang waktu bulan Februari hingga Juli 2015. 
Tabel 4.

Perubahan Nilai Baseline

\begin{tabular}{|c|c|c|c|c|}
\hline \multirow{2}{*}{ Stasiun } & \multicolumn{2}{|c|}{ Baseline } & \multirow{2}{*}{$\begin{array}{c}\text { Nilai } \\
\text { Perubahan }\end{array}$} & \multirow{2}{*}{$\begin{array}{c}\text { Indikasi } \\
\text { Deformasi }\end{array}$} \\
\hline & Awal (m) & Akhir (m) & & \\
\hline DELS & 26978,2442 & 26978,2344 & 0,00984 & $\mathrm{Ya}$ \\
\hline GRWH & 31501,2329 & 31501,2472 & $-0,01426$ & $\mathrm{Ya}$ \\
\hline KLAT & 29889,4824 & 29889,4797 & 0,00276 & Ya \\
\hline
\end{tabular}

Selain perubahan panjang baseline aktivitas deformasi juga dapat ditunjukkan dengan perubahan tinggi setiap stasiun. Apabila perubahan condong ke arah positif maka dapat dikatakan gunung tersebut mengalami inflasi, sedangkan apabila condong ke arah negatif maka gunung tersebut mengalami deflasi. Berikut ini merupakan grafik perubahan tinggi titik pengamatan GPS Gunung Merapi dalam waktu 6 bulan:

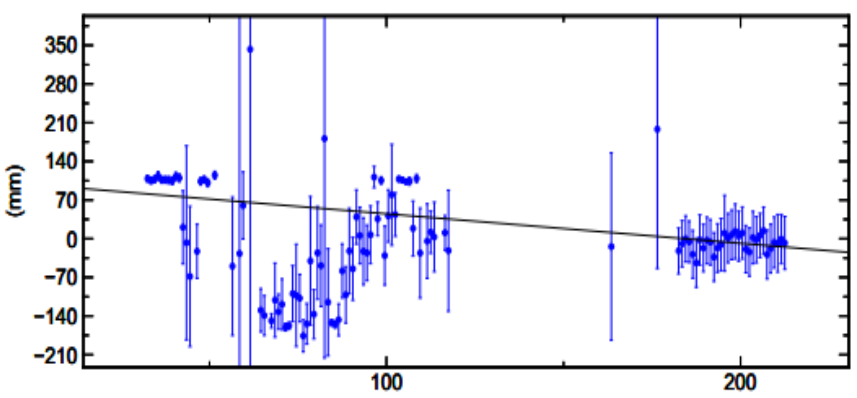

Gambar 4. Perubahan Tinggi Stasiun DELS Bulan Februari-Juli 2015

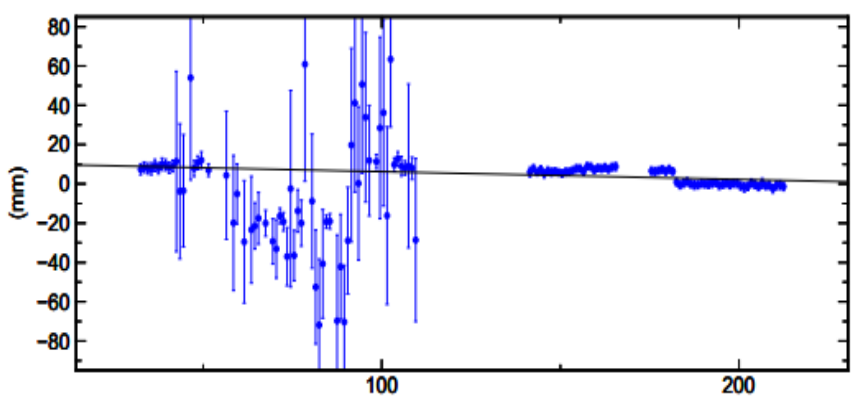

Gambar 5. Perubahan Tinggi Stasiun GRWH Bulan Februari-Juli 2015

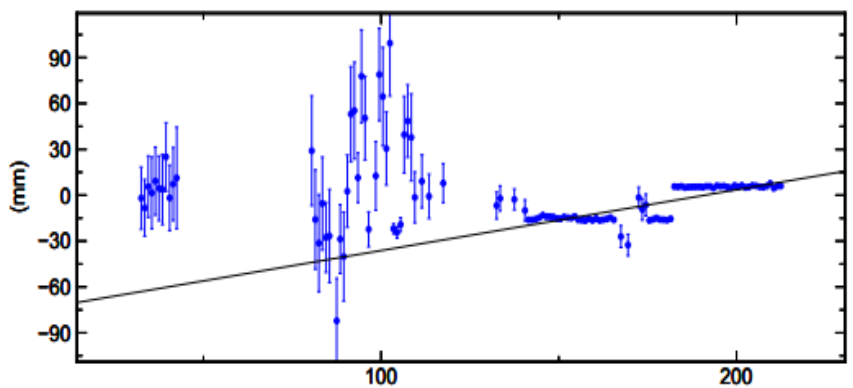

Gambar 6. Perubahan Tinggi Stasiun KLAT Bulan Februari-Juli 2015

Dari hasil Tabel 4 beserta Gambar 4, Gambar 5, dan Gambar 6 dapat terlihat bahwa stasiun pengamatan DELS dan KLAT mengalami pemanjangan baseline terhadap base BPTK yang terdapat pada arah selatan Gunung Merapi (Gambar 3) sebesar 0,00984 meter dan 0,00276 meter, sedangkan stasiun pengamatan GRWH mengalami pemendekan sebesar -0,01426 meter. Untuk perubahan tinggi titik selama 6 bulan, stasiun DELS dan GRWH mengalami penurunan yang dapat diindikasikan sebagai deflasi sedangkan stasiun KLAT mengalami kenaikan yang dapat diindikasikan sebagai inflasi.

Aktivitas yang terjadi pada sumber tekanan pada dapur magma memberikan interaksi yang terekam pada permukaan Gunung Merapi, hal tersebut dapat terlihat dari arah pergerekan vektor pada Gambar 3. Dapat dilihat dari stasiun DELS dan stasiun GRWH yang terletak di sebelah tenggara dan utara dari puncak Gunung Merapi mengalami pergeseran yang sama ke barat menuju ke sumber tekanan dengan sifat deflasi, sedangkan stasiun KLAT yang berada di sebelah barat laut dari sumber tekanan mengalami pergeseran ke tenggara dengan aktivitas inflasi. Aktivitas diatas dapat mencerminkan prediksi pola pergerakan magma dari arah barat menuju timur dan arah pergeseran membentuk pola radial searah di sekitar sumber tekanan. Selain itu, inflasi pada tubuh Gunung Merapi mengindikasikan bahwa telah terjadi aktivitas dari sumber magma yang menekan tubuh gunung sehingga perlu adanya peneltitian lebih lanjut terhadap aktivitas Gunung Merapi.

\section{KESIMPULAN DAN SARAN}

Adapun beberapa hal yang bisa disimpulkan dari penelitian ini adalah:

1. Arah dan besar pergeseran dari titik pengamatan GPS Gunung Merapi pada bulan Februari hingga Juli 2015 didapatkan nilai pergeseran horizontal sebesar 0,01822 meter menuju ke arah barat laut dan vertikal sebesar 0,06924 meter dengan sifat deflasi untuk stasiun DELS, horizontal sebesar 0,030508 meter menuju ke arah barat daya dan vertikal sebesar $-0,00875$ meter dengan sifat deflasi untuk stasiun GRWH, horizontal sebesar 0,025822 meter menuju ke arah tenggara dan vertikal sebesar 0,07725 meter dengan sifat inflasi untuk stasiun KLAT.

Dari beberapa kesimpulan diatas, dapat dikemukakan saransaran untuk penelitian selanjutnya sebagai berikut:

1. Dalam upaya mitigasi dari bencana gunung api diperlukan suatu upaya integrasi dari beberapa metode, selain metode deformasi untuk memberikan hasil yang lebih akurat terkait penentuan arah, besar dan sumber tekanan magma gunung api. Beberapa metode yang dapat menunjang antara lain seperti metode gaya berat, metode seismik, metode geokimia, dll.

2. Perlunya pertimbangan dalam aspek pemilihan stasiun beserta kelengkapan data dari stasiun bersangkutan yang bertujuan untuk meningkatkan nilai kelaikan dari deformasi GPS

\section{UCAPAN TERIMA KASIH}

Penulis Y.G.W mengucapkan terima kasih kepada Balai Penyelidikan dan Pengambangan Teknologi Kebencanaan Geologi (BPPTKG) Yogyakarta yang telah memberikan izin untuk melakukan penelitian serta kepada Ibu Sulistiyani selaku pembimbing. 


\section{DAFTAR PUSTAKA}

[1] Balai Penyelidikan dan Pengembangan Teknologi Kebencanaan Geologi. Sejarah Merapi. www.merapi.bgl.esdm.go.id/informasi diakses pada tanggal 28 April 2016 pada pukul 20.34 WIB.

[2] Asriningrum, dkk. 2004. Pengembangan Metode Zonasi Daerah Bahaya Letusan Gunung Api Studi Kasus Gunung Merapi. Jurnal Penginderaan Jauh dan Pengolahan Data Citra Digital, Vol.1, No.1, 2004.

[3] Abidin, H.Z. 2007. Penentuan Posisi dengan GPS dan Aplikasinya. Jakarta : PT Pradnya Paramita.

[4] King, R.W., Herring, T.A., McClusky, S.C. 2010. GAMIT Reference Manual, Release 10.40, Departement of Earth, Atmospheric, and Planetary Sciences, Massachutes Institute of Technology, Oktober.

[5] Wolf, Paul R dan D. Ghilani, Charles. 2006. Adjusment Computations Spatial Data Analysis. New Jersey : John Wiley \& Sons, Inc. 